\title{
Minando o sistema republicano-liberal desde dentro. Os partidos políticos portugueses no contexto Europeu e Ibérico $(1919-1926)^{*}$
}

\author{
Undermining the republican-liberal system from within. Portuguese political parties \\ in the European and Iberian context (1919-1926)
}

\section{Manuel Baiôa}

Doutor em História Contemporânea Investigador do CIDEHUS, Universidade de Évora manuelbaioa@hotmail.com

Resumo: Neste artigo analisamos a evolução dos partidos políticos portugueses após a I Guerra Mundial, inserindo-os no contexto europeu e ibérico. Os partidos políticos portugueses modernizaram-se neste período, mas não se transformaram em partidos de massas. Nas principais cidades atuavam como partidos de quadros e nos meios rurais como partidos de notáveis. Durante a fase final da Primeira República (1919-1926) não se deram passos consistentes para a democratização do sistema político e os partidos nem conseguiram chegar a acordos mínimos que defendessem o sistema republicano-liberal. Portugal continuou amarrado à tradição liberal e oligárquica do século XIX, ainda que numa versão republicana e com um sistema multipartidário de partido dominante com uma crescente falta de legitimidade.

Palavras-chave: Primeira República Portuguesa, Partido Republicano Português, partido de notáveis.

\begin{abstract}
In this article we analyze the evolution of the Portuguese political parties after World War I, inserting them in the European and Iberian context. The Portuguese political parties were modernized in this period, but did not become mass parties. In the main cities they served as parties of cadres and in the rural areas as parties of notables. During the final stage of the First Republic (1919-1926), no consistent steps were taken to democratize the political system and the parties failed to agree in defending the liberal-republican system. Portugal remained tied to the liberal and oligarchic tradition of the nineteenth century, though in a republican version and with a multiparty system of dominant party with an increasing lack of legitimacy.
\end{abstract}

Keywords: Portuguese First Republic; Portuguese Republican Party; party of notables.

\footnotetext{
* Este trabalho é financiado por fundos nacionais através da Fundação para a Ciência e a Tecnologia e pelo Fundo Europeu de Desenvolvimento Regional (FEDER) através do COMPETE 2020 - Programa Operacional Competitividade e Internacionalização (POCI) e PT2020, no âmbito do projeto UID/HIS/00057 - POCI-01-0145-FEDER-007702.
} 


\section{0 Contexto Europeu}

A I Guerra Mundial e os posteriores Tratados de Paz provocaram um forte impacto na sociedade europeia, tendo sido catalisadores de profundas transformações políticas e sociais que tinham começado antes da guerra e que se afirmaram definitivamente nos anos vinte e trinta. Este período ficou marcado, em muitos países, por uma alteração no equilíbrio social e pela transição entre um período caracterizado pelo liberalismo e pelos partidos de notáveis e uma época em que se afirmou a democracia-liberal, a socialdemocracia, o fascismo/autoritarismo e os partidos de massas. O pós-guerra foi um período marcante em toda a Europa para se avaliar a capacidade dos partidos políticos na adaptação ao crescente dinamismo da sociedade. Verificou-se um aumento da mobilização social com um crescimento exponencial do associativismo operário e patronal e de outros grupos de pressão e o aparecimento de uma opinião pública consciente e ativa. Uma parte da sociedade que tinha estado afastada da política tinha novas reivindicações e expectativas que colocaram sob pressão os sistemas políticos de muitos países (ORSINI \& QUAGLIARIELLO, 1996; LUEBBERT, 1997; BERGSCHLOSSER \& MITCHELL, 2000; MENESES, 2004).

A mobilização solicitada pelos estados aos cidadãos para se integrarem no esforço de guerra acarretou, posteriormente, o aparecimento de movimentos de ex-combatentes e de um crescimento da participação política com a extensão da cidadania (sufrágio universal) em muitos países e com ajustamentos nos regimes eleitorais num sentido mais democrático (implementação do sistema proporcional e outras reformas eleitorais) e com o aparecimento de novas formas de representação (sindical, orgânica e técnica). Estas alterações exerceram uma forte pressão sobre o sistema político e desenvolveram uma enorme expectativa na sociedade que procurava mudanças rápidas que nem sempre as organizações tradicionais estavam em condições de proporcionar. A revolução bolchevique e o posterior aparecimento dos partidos comunistas e radicais nacionalistas marcaram a agenda política ao acentuarem as clivagens e os conflitos existentes na sociedade entre patrões e operários e entre capitalismo e socialismo. A I Guerra Mundial marcou uma fronteira para a afirmação da democracia em detrimento dos sistemas unicamente representativos, tendo a política passado a fazer parte da vida de uma grande parte dos europeus (SILVA, 1996: 19-21; VARELA ORTEGA, 1997a; RIDOLFI, 1999: 284-321). 
Será que os partidos políticos europeus estavam preparados para se adaptarem a esta nova sociedade que despontava? Procuraram ajustar a sua experiência organizativa às novas exigências políticas? Alguns novos partidos europeus surgiram com uma ideologia e um modelo organizativo aparentemente mais adaptado aos problemas da sociedade europeia do pós-guerra: os modernos partidos de massas tinham uma ideologia coerente, uma organização permanente e fortemente estruturada, seguiam um modelo centralista, disciplinado, hierarquizado, burocratizado e racionalizado, possuíam uma elite profissional dedicada em exclusivo à política e tinham uma intensa participação dos aderentes que encontravam no partido um lugar de formação, educação, bem-estar e integração na sociedade através de uma disciplina e fidelidade ideológica. Aos partidos políticos dos anos vinte era-lhes pedido que conseguissem acolher, moderar e encaminhar para o sistema político os pedidos e exigências, já não só dos estratos burgueses, mas também de vastos grupos sociais recentemente chegados à política, evitando quanto possível petições desproporcionadas e revolucionárias que pudessem por em perigo o equilíbrio da sociedade e do sistema político. A adoção da representação proporcional e do sufrágio universal masculino tornaram, por vezes, difícil a formação de maiorias coesas, facto que foi aproveitado pelos novos partidos para minar ainda mais a credibilidade dos regimes e dos partidos de notáveis democrático-liberais do pós-guerra. Por outro lado, em muitos países intensificou-se o debate e o conflito político interno dentro dos partidos, entre a classe política burocrática em ascensão e a antiga elite formada por parlamentares e caciques locais. As respostas dadas pelos partidos políticos à modernização da sociedade diferiram muito de país para país, embora quase todos eles tenham tentado adaptar-se aos novos tempos. Contudo, um traço geral parece marcar este período do pós-Guerra. Nas sociedades que se abriram mais fortemente à era das massas e que permitiram o acesso mais alargado à cidadania e a um sistema representativo mais justo, houve uma decadência de muitos partidos de notáveis liberais, como o Partido Radical Francês, o Deutsche Volkspartei (Partido Popular Alemão, DVP), o Deutsche Demokratische Partei (Partido Democrático Alemão, DDP), o Partido Liberal Italiano e o Partido Liberal Inglês. Pelo contrário, alguns dos novos partidos de massas ou de integração social obtiveram resultados expressivos na Grã-Bretanha, Suíça, França, Holanda, Bélgica, Dinamarca, Noruega e Itália. O SPD (Partido Social Democrata Alemão) e o PSI (Partido Socialista Italiano) foram mesmo os mais votados e o Partido Trabalhista Inglês (Labour Party) conseguiu ser pela primeira vez o segundo partido do sistema político britânico. As organizações de interesses transformadas em partidos com 
exigências específicas tiveram algum êxito na Europa ${ }^{1}$, tendo os partidos confessionais como o Centro Católico Alemão (Zentrum) e o Partido Popular Italiano conseguido ser as segundas forças políticas nas eleições de 1919 (SILVA 1996: 19-21; SABBATUCCI, 1996; SERNERI, 1996; QUAGLIARIELLO, 1996; LUEBBERT, 1997; LOPES, 2004: 29-49).

As respostas dadas pelos partidos políticos aos problemas do pós-guerra e à crise do liberalismo foram variadas. Em alguns países, como em França, no Reino Unido, na Bélgica, na Checoslováquia e na Finlândia, os partidos conseguiram superar as ameaças sobre o sistema democrático-liberal, tendo reforçado inclusive a legitimidade e a eficácia das instituições democráticas. Uma coligação estável dos principais partidos que defendiam a democracia e o pluralismo protegeu o sistema político destes países dos ataques das organizações extremistas, através de uma combinação de estratégias repressivas e inclusivas. Donde, os partidos que defendiam a democracia reagiram contra as forças políticas radicais que exploravam os direitos e garantias da democracia para minar as suas bases fundamentais, isolando-as e debilitando-as. Noutros países, como na Itália e na Alemanha, os partidos tradicionais não conseguiram liderar a formação de um consenso político, o que levou à radicalização e à debilidade dos moderados e do centro democrático (LINZ, 1991; SILVA, 1996: 19-21; LUEBBERT, 1997; ERTMAN, 1998; BERG-SCHLOSSER \& MITCHELL, 2000; CAPOCCIA, 2001).

\section{0 Contexto Ibérico}

Em Portugal e Espanha o pós-Guerra não trouxe mudanças no sentido de alargar a cidadania e não se deram passos para introduzir o sistema proporcional, nem círculos mais coerentes, como em Itália em 1918-19. Continuaram a persistir índices de abstenção elevados e os partidos políticos continuaram a negligenciar a integração social e política das massas, agravada em Portugal pela capacidade eleitoral continuar limitada aos homens alfabetizados, o que afastou do sufrágio a larga maioria dos operários e trabalhadores rurais, sendo nesse momento uma exceção na Europa Ocidental (ALMEIDA, 1998; ALMEIDA \& MORENO LUZÓN, 2012).

\footnotetext{
${ }^{1}$ Veja-se a o Centro Católico Português e a União dos Interesses Económicos em Portugal, os partidos agrários da Itália, Checoslováquia, Estónia, Finlándia, Hungria, Polónia, Roménia e Suécia e os partidos das minorias etnicas da Europa Oriental (BERG-SCHLOSSER \& MITCHELL, 2000).
} 
O clientelismo nos países ibéricos assentava ainda fundamentalmente no papel dos caciques e não tanto nos partidos políticos enquanto organizações. Os notáveis e alguns políticos profissionais continuaram a dominar o "mercado político", ocupando o poder executivo e subordinando o legislativo. A luta pelo poder continuou a centrar-se no controlo do poder executivo, o que atrasou o processo democrático, dado que houve uma menor integração dos interesses sociais e da participação dos cidadãos, sendo a fraude administrativa dominante e a corrupção marginal nos processos eleitorais, enquanto nos países mais desenvolvidos acontecia o inverso. Aquelas mudanças não foram requeridas intensamente pela sociedade nem foram sugeridas pelos partidos. Estes mostraram que não estavam preparados e motivados para agrupar, modelar, moderar e canalizar para o sistema político os interesses e as exigências políticas de todos os estratos sociais. A continuação das práticas clientelares dos partidos de notáveis, a pouca lisura nos atos eleitorais e a ineficácia dos órgãos de soberania acentuaram a crise de legitimidade das instituições políticas (avultada em Portugal por não ter adotado o sufrágio universal masculino) e empurraram para fora do sistema político vastos grupos da sociedade que desenvolveram petições maximalistas e atividades revolucionárias (LINZ \& STEPAN, 1978; GRAZIANO, 1980; CAZORLA PÉREZ, 1992; MORENO LUZON, 1995, 1999, 2006; ROBLES EGEA, 1996: 229-251; SILVA, 1996: 19-21; SILVA, 1997; VARELA ORTEGA, 1997b; BAIÔA, 2013).

Nas sociedades onde os partidos estavam subdesenvolvidos, as personalidades ganhavam um relevo fundamental. A representação dos interesses não era canalizada pela «organização partido», mas por um conjunto de notáveis que acautelavam as suas causas, interesses e protegidos, criando inúmeras redes de favores cruzados, muitas vezes incompatíveis dentro do mesmo partido. A organização partidária modernizou-se pouco, continuando com a mesma estrutura personalista de carácter oligárquico e caciquil que afastava a maioria dos seus membros das decisões e mantinha a população afastada da política. Os atos eleitorais internos e externos continuaram pouco transparentes ${ }^{2}$ e não foi

\footnotetext{
${ }^{2}$ Ramada Curto, líder do Partido Socialista Português, defendia que o seu partido era a terceira força política portuguesa. Embora nas eleições legislativas não conseguissem passar do sexto ou sétimo partido com mais mandatos. Veja-se a sua explicação: “O Partido Socialista é a terceira força política organizada da República. Não lhe falo das eleições da província, visto que como na Monarquia, são feitas pelo caciquismo e a organização partidária a que pertenço em vez de captar repudia e guerreia o cacique, entidade imoral, antidemocrática. Duas eleições existem relativamente livres que correspondem de facto a correntes de opinião definidas e extremadas: são as que se fazem em Lisboa e Porto. Pois, no Porto o nosso partido é a segunda potência eleitoral”, A Tarde, Lisboa, 4-12-1923, 1.
} 
possível consolidarem-se novos partidos de integração social que renovassem os líderes políticos e os seus procedimentos. Esta imagem de organização clientelar transparecia para a opinião pública por meio de uma imprensa cada vez mais ácida em relação à ineficácia dos partidos e do Parlamento (SILVA, 1996; VARELA ORTEGA, 2001; BAIÔA, 2004, 2015; MORENO LUZÓN, 2006; QUEIRÓS, 2008).

No entanto, convém salientar que esta realidade não era monolítica nem eterna. Quase todos os partidos iniciaram uma aproximação a um modelo de partido moderno e funcional, como o Partido Radical, o Maurismo e a Lliga Regionalista da Catalunha em Espanha, o Partido Radical em França e o Partido Republicano Português (PRP) em Portugal. Com exceção do Partido Radical francês, todos os outros falharam na tentativa de se transformarem em partidos de massas devido ao:

desajuste e afastamento progressivo entre, por um lado, as reivindicações [...] [das] bases urbanas de um partido mais democratizado, mais participado, com uma estrutura interna de oportunidades mais aberta aos impulsos e protagonismos vindos de baixo e, por outro lado, a conceção elitista de um partido de notáveis que não quiseram abdicar das suas conceções monopolistas, hierárquicas e fechadas do poder, nem criar os mecanismos endógenos de regulação, representação e retribuição que tornassem o partido mais pluralista, mais aliciante e, também, mais funcional (Silva, 1996: 75).

Dado que alguns partidos de notáveis na década de vinte já não tinham as mesmas características dos partidos do século XIX, alguma historiografia espanhola remodelou o conceito de "partido de notáveis" de Max Weber e o conceito de "partido de quadros" de Maurice Duverger. Os partidos que não se modernizaram continuariam a ser designados por partidos de notáveis, enquanto os que iniciaram uma modernização seriam designados por partidos de quadros. Desta forma os partidos de quadros representavam uma fase de transição na evolução dos partidos. Tinham perdido algumas das características tradicionais dos partidos de notáveis, uma vez que passaram a ter uma estrutura burocrática e organizativa quase permanente, uma elite mais diversificada e preparada para a política de massas e uma maior mobilização e enquadramento dos aderentes, mas ainda não tinham as características dos partidos de massas. Utilizavam uma estratégia política mista em simultâneo, com uma prática política moderna mais acentuada nos meios urbanos e uma política clientelar nos meios rurais. Entre as práticas políticas 
modernas podemos destacar o percurso dos candidatos pelo círculo em campanha eleitoral, a confraternização com os votantes, o comício, a eleição dos candidatos no seio do partido, a elaboração de um programa e a obtenção de favores para toda a coletividade e já não só para alguns indivíduos da mesma comunidade. As práticas tradicionais continuaram a persistir, em particular nos meios rurais, como a compra do voto, a ação dos caciques, a violência, a coação sobre os trabalhadores por parte do seu patrão, a intervenção do governador civil e de outros membros da administração pública, a fraude e a manipulação final dos resultados eleitorais (ARRANZ NOTARIO, 1995; SIERRA, 1996; PEÑA GUERRERO, 1998; VARELA ORTEGA, 2001; MORENO LUZÓN, 2006).

As investigações têm revelado uma maior resistência à democratização por parte das elites partidárias locais. Estes caciques demonstraram um crescente temor perante o início da mobilização das classes médias e populares. Desenvolveram, por isso, atitudes de prevenção perante a emergência da política de massas e refugiaram-se em posições antirreformistas para manter o sistema. Todavia, os líderes partidários nacionais também não souberam criar os mecanismos necessários para dar passos seguros na democratização dos países ibéricos (SUÁREZ CORTINA, 1997: 9-29; RIQUER I PERMANYER, 1999; BAIÔA, 2000).

Este atraso na modernização dos partidos políticos em Portugal e Espanha acompanhava o atraso das suas sociedades e das suas economias face a outros países mais dinâmicos como a França, Alemanha e Reino Unido, ou até mesmo a Itália. Na verdade, uma grande diversidade de fatores contribuiu indiretamente para a modernização dos partidos e sistemas partidários destes países, entre os quais têm sido destacados a expansão da industrialização e da urbanização, o desenvolvimento e integração do mercado interno, o crescimento do associativismo, o incremento da secularização social, a generalização dos bens e serviços sociais (seguros sociais, saúde, informação e educação), a progressiva eliminação do analfabetismo, o crescimento da escolarização intermédia e superior, que facilitou a passagem de uma cultura política clientelar e de sujeição para uma cultura política de mobilização e de participação. Sem estas condições era difícil desenvolverem-se partidos de origem extraparlamentar, como socialistas, comunistas, social-democratas ou fascistas, que pretendiam enquadrar as massas que aspiravam a participar no processo político. No entanto, convém realçar que o sistema político e social português estava mais distante dos países da Europa ocidental do que o espanhol. 
Portugal e Espanha viveram no pós-Guerra o fenómeno da fragmentação partidária fruto da modernização da sociedade e do facto dos seus partidos de notáveis sentirem fortes dificuldades na adaptação à era das massas. Em Espanha, a pulverização dos grupos parlamentares foi mais acentuada (mais do que novos partidos surgiram cisões nos dois principais partidos) e condicionou fortemente a instabilidade governativa. Em Portugal, ainda que se tenha mantido um sistema multipartidário de partido dominante, tal não significou maior estabilidade política. A fragmentação deu-se principalmente nos partidos do centro político e não derivou normalmente de diferenças ideológicas ou estratégicas, mas de diferenças pessoais entre os líderes. Assim, os países ibéricos que tinham um sistema partidário que aparentemente deveria criar condições de maior estabilidade política, dado que os partidos radicais de esquerda e direita eram minoritários, não conseguiram obter consensos que fizessem estabilizar o sistema governativo. Portugal apresentava o maior índice de instabilidade governativa da Europa no período anterior à grande depressão, com uma duração média de 117 dias por cada executivo (16/05/1918 a 28/05/1926). A Espanha também tinha um lugar no pódio, dado que ocupava o terceiro lugar com uma média de 166 dias (21/03/1918 a 13/09/1923). Não se pode estranhar, por isso, que parte da opinião pública pensasse que o Estado estava à deriva nas mãos de uns políticos incapazes (LINZ, 1991; MARTORELL LINARES, 2012).

Em Portugal, a hegemonia conseguida pelo Partido Republicano Português (vulgarmente conhecido por Partido Democrático) desde 1910 condicionou fortemente o regime republicano. Houve uma incapacidade de encontrar mecanismos pacíficos de alternância ou de governação estável, dado que "durante a República, por sistema, não havendo confiança no funcionamento do sistema eleitoral, é às armas que se recorre para chegar ao poder. São as revoluções e não as eleições que asseguram a alternância política" (COSTA, 2001: 69), uma vez que se vivia num regime de eleições fraudulentas e injustas. Nenhum partido confiava nos resultados das eleições, mas todos estavam implicados em procedimentos ilegais e não houve por parte deles um esforço para melhorar a lisura e a transparência das eleições. A indisciplina e a fragmentação partidária, a oposição dos Presidentes da República a alguns ministérios exclusivos do Partido Republicano Português e o seu desejo de formar executivos frentistas, aglutinando e liderando todas as forças republicanas, levou a que fosse impossível governar sem ele (PRP), mas que fosse também muito difícil que este governasse sozinho. Esta enorme instabilidade 
governativa coincidiu assim, com a ausência de uma política competitiva e pluralista em Portugal.

Na Espanha monárquica, o sistema do "turno" criado pela constituição de 1876 começou a deteriorar-se com a morte dos líderes do partido conservador (Antonio Cánovas em 1897) e do partido liberal (Práxedes Sagasta em 1903), tendo-se acentuado claramente a partir de 1913 e 1917 quando estes dois partidos entraram numa crescente crise interna que levou à sua cisão. Estas dissidências ocorreram em simultâneo com o desenvolvimento de novos agrupamentos políticos que não se reviam no sistema da Restauração. O novo quadro partidário fragmentado teve reflexos imediatos no Parlamento e no Executivo. Os governos de coligação passaram a ser a regra e não a exceção, pelo que deixou de haver governos estáveis apoiados por maiorias consistentes e a relação entre o poder legislativo e o executivo tornou-se cada vez mais difícil. Por outro lado, as eleições passaram a ser mais disputadas e a não dar vitórias certas ao governo. O Rei teve de tomar uma atitude mais interventiva face a um Parlamento com maiorias instáveis e minorias fortes e combativas (MORENO LUZÓN, 1998a; DARDÉ, 2012; MARTORELL LINARES, 2012).

Estes fenómenos políticos ao coincidirem com os efeitos da participação de Portugal na I Guerra Mundial e da participação da Espanha na Guerra de Marrocos, com a agitação social, as greves e o «perigo vermelho», suscitado pelas consequências da revolução russa de 1917, criaram na sociedade conservadora ibérica uma imagem de descrédito do Parlamento, dos partidos e dos políticos em geral e um receio da revolução social. Uma parte significativa da elite conservadora defendeu uma substituição do sistema de representação liberal e parlamentar, por fórmulas de representação corporativa (REY REGUILLO, 1992; LEAL, 2009a).

Nos anos vinte, tanto em Espanha como em Portugal, houve um largo consenso na imprensa quanto à necessidade urgente de reformar os regimes e os próprios partidos descredibilizados. As dúvidas surgiam relativamente às soluções. No entanto, dado que não havia sinais significativos de um processo reformador interno por parte da elite e das instituições políticas dos regimes, esse processo teve de partir do exterior. As Forças Armadas eram a organização mais preparada e prestigiada para dar início a este processo. Os militares passaram a intervir mais ativamente na política, tanto pela via legal, como pela via anticonstitucional. Os golpes militares que implantaram as Ditaduras Militares em Espanha e Portugal, em 1923 e 1926, viriam a ter um apoio de uma parte significativa da opinião pública, principalmente em relação ao discurso regenerador e crítico do 
funcionamento oligárquico dos partidos e das instituições políticas da Restauração e da I República. Quase todos os sectores políticos compreendiam a urgência de uma mudança e uma renovação no sistema político (CARRILHO, 1985; SECO SERRANO, 1986; FERREIRA, 1992; ROSAS, 1994: 151-241; OLABARRI GORTAZAR, 1996; RAMOS, 2000; AFONSO, 2001; TELO, 2011).

Os partidos estruturais da Restauração e da I República desapareceram no decurso da Ditadura Militar. O discurso e a ação anti-partidária do novo regime e o esvaziamento do papel dos antigos partidos, enquanto mediadores do clientelismo, contribuíram decisivamente para o fim inglório destas organizações políticas. Sem Parlamento, sem liberdades civis e sem acesso ao poder, os partidos enfrentaram uma difícil travessia sob o novo regime autoritário. As suas magras estruturas ligadas à repartição dos recursos políticos deixaram de funcionar na maior parte das regiões, ainda que muitos vínculos pessoais permanecessem vivos ao longo de muitos anos. A capacidade de manobra das formações que tinham governado Portugal e Espanha desvaneceu-se e a ação dos principais notáveis de cada grupo ficou muito limitada devido à hostilização a que eram submetidas pela Ditadura. Esta situação viu-se agravada, em Portugal, pela forte resistência armada que alguns políticos do PRP e de outros partidos esquerdistas enveredaram logo que verificaram que a Ditadura não ia ao encontro dos seus interesses. O fortalecimento das medidas repressivas e autoritárias por parte da Ditadura portuguesa contra os políticos e contra os partidos foi, em parte, um reflexo do radicalismo do «reviralho». As águas estavam separadas! Este facto levou a direita conservadora a esquecer momentaneamente as divergências internas e a aceitar o modelo autoritário imposto pelos Militares e por Salazar face ao perigo da Ditadura jacobina que os reviralhistas propunham. Muitos políticos republicanos ordeiros recusaram o regresso ao passado e conformaram-se com o regime que a Ditadura lhes proporcionava. Outros, porém, viriam a apoiar com maior ou menor vigor a obra do Estado Novo. Em Espanha, o facto de os pronunciamentos militares contra a Ditadura terem tido menor impacto e terem sido liderados por alguns dos antigos líderes dos partidos dinásticos que tinham sido saneados pela Ditadura, levou a que continuasse a existir uma clivagem dentro da direita entre os apoiantes da Ditadura e do Rei, e os críticos do Regime de Primo de Rivera (SECO SERRANO, 1986; GÓMEZ-NAVARRO, 1991: 433-444; ROSAS, 1994: 151241; JULIÁ, 1996; MORENO LUZÓN, 1998b; FARINHA, 1998; RAMOS, 2000; BAIÔA, 2015). 
Enquanto em Espanha os militares intervieram na política para sanearem um regime em crise dominado por políticos monárquicos, conservadores e liberais; em Portugal, os militares tomaram a iniciativa de reformularem um regime dominado por republicanos ordeiros de tradição radical. Este facto tornou mais fácil a adesão da direita portuguesa à Ditadura Militar, dado que a alternativa que existia era o regresso a uma segunda república jacobina. Em Espanha a situação era mais complexa, uma vez que parte da direita tinha sido afastada do Poder pelo golpe de Primo de Rivera, e a evolução do Regime e das suas instituições, como a União Patriótica, não conseguiram mobilizar toda a direita no seu projeto. Por outro lado, o perigo republicano e vermelho, não parecia à primeira vista tão próximo, o que tornou impossível unir toda a direita espanhola no projeto de regeneração da Pátria liderado por Primo de Rivera. A ditadura espanhola destruiu os partidos monárquicos e a União Patriótica ao assumir e consumir todas as energias reformistas da direita, deixou a Monarquia nas mãos dos republicanos que aproveitaram este período para se reorganizarem e para se unirem na Aliança Republicana. Em Portugal, pelo contrário, Salazar acabaria por conseguir levar as "direitas" a estabelecer um consenso possível para desenvolver um projeto autoritário de “regeneração da Nação” (ÁLVAREZ REY, 1987; GÓMEZ-NAVARRO, 1991: 524-529; FERREIRA, 1992; ROSAS, 1994: 151-241; RAMOS, 2000).

\section{Portugal: fracasso na edificação da democracia e dos partidos de massas}

Durante a I República portuguesa manteve-se quase permanentemente um sistema multipartidário de partido dominante, mas com uma elevada instabilidade política. Portugal teve 45 governos, 29 tentativas de golpe de Estado, sete eleições gerais (mais a eleição parcial de 1913) e oito presidentes entre 1910 e 1926, pelo que era claramente naquele período o país europeu com maior instabilidade governativa da Europa. Se a comparação for feita com a fase final da Monarquia portuguesa, também caracterizada por uma grande instabilidade política, a duração dos governos republicanos foi quase quatro vezes inferior. A instabilidade política agravou-se após a I Guerra Mundial, como consequência da crise económica e financeira e de uma maior fragmentação partidária, a que não ficará alheio o maior partido da República - o Partido Republicano Português 
(SOUSA, 1983: 167-177; LOPES, 1990; LINZ, 1991; LEAL, 2009b; MATOS, 2010: 89113; FERNANDES, 2012).

A instabilidade governativa derivou essencialmente de dois problemas. Em primeiro lugar, o Partido Republicano Português (PRP), embora teoricamente dominasse o Parlamento, não dispunha de uma maioria coesa e não conseguiu criar consensos internos que dessem estabilidade ao poder executivo. O PRP e as suas várias fações internas formaram essencialmente governos de coligação, com o apoio de outros partidos e de deputados independentes, o que favoreceu a discórdia dentro do PRP e o aparecimento de fações e cisões. Durante largos períodos o Diretório do PRP não controlou o seu grupo parlamentar. Por isso, muitos governos do PRP caíram com votos de parlamentares do seu próprio partido. Os diretórios dos partidos não conseguiam disciplinar os seus deputados e senadores, uma vez que os parlamentares tinham uma legitimidade própria ganha nas eleições e por isso votavam no Parlamento com grande liberdade, contrariando muitas vezes a orientação do partido. Todos os partidos eram constituídos por várias fações radicais e moderadas, o que dificultava a coesão partidária. O quadro constitucional criado pela República deu um vasto poder ao Parlamento, em detrimento do executivo, o que favoreceu a instabilidade política. Em segundo lugar, houve uma incapacidade de encontrar mecanismos pacíficos de alternância ou de governação estável. Durante a I República houve uma limitada competição interpartidária e continuou a viver-se num regime de "eleições fabricadas e não justas" que proporcionavam a vitória sistemática do partido do governo através de vários mecanismos de "engenharia eleitoral", entre os quais se destacavam a falsificação do recenseamento eleitoral, os acordos ilícitos entre todos os candidatos de um círculo eleitoral que decidiam antecipadamente o resultado final das eleições, a «compra» de votos, a violência eleitoral, a fraude, e por fim, as decisões tendenciosas das assembleias de apuramento e das comissões de verificação de poderes. Por isso, os partidos da oposição não tendo confiança no funcionamento do sistema eleitoral e afastados das fontes de distribuição de favores, recorreram à violência e às revoluções para chegar ao poder. Na Monarquia Constitucional o Rei podia demitir o governo, nomear um novo governo da oposição, dissolver o Parlamento e marcar novas eleições que davam a vitória ao partido do governo. Este mecanismo de alternância política permitiu esbater durante algum tempo as tensões políticas. Durante a I República o sistema constitucional limitou esta prática. Assim, muitos políticos enveredaram pelos golpes de Estado para chegar ao governo, uma vez que o sistema eleitoral e constitucional não lhes abria essa possibilidade. A violência 
e a revolução tornaram-se fontes de legitimação da alternância política que posteriormente a "soberania do povo" validava (LOPES, 1994, 2011, 2013b; FREIRE, 2011; ALMEIDA \& MORENO LUZÓN, 2012; BAIÔA, 2015).

As várias fórmulas governativas ensaiadas (governos maioritários, minoritários, monopartidários, de coligação, de concentração, de fação e de iniciativa presidencial) não tiveram sucesso duradouro devido principalmente às lutas internas no partido dominante da I República (PRP). Portugal manteve uma instabilidade política endémica, embora tivesse aparentemente um sistema partidário capaz de criar condições de grande estabilidade política. Os partidos radicais de esquerda e direita eram minoritários (o Partido Comunista Português e os movimentos e partidos fascistas nunca conseguiram eleger um deputado ou senador) e o Partido Republicano Português dominava aparentemente o Parlamento. A fragmentação partidária deu-se principalmente nos partidos do centro político e não derivou normalmente de grandes divergências ideológicas, mas de diferenças pessoais entre os líderes. Durante vários anos a desunião do grupo parlamentar do PRP permitiu que os partidos da oposição tivessem algumas veleidades de aceder ao poder executivo, mas após as eleições de novembro de 1925 o Partido Republicano Português passou a contar finalmente com um grupo parlamentar mais coeso e com uma maioria absoluta no Congresso, o que favoreceu um pacto entre vastos sectores políticos da direita e da esquerda no sentido de prepararem um golpe militar que retirasse o PRP do poder. Este golpe militar acabaria por concretizar-se em 28 de maio de 1926 (SCHWARTZMAN, 1989; MATOS, 2010; TELO, 2011; FERNANDES, 2012; BAIÔA, 2015).

Em Portugal o pós-guerra não trouxe reformas no sentido de alargar a cidadania, uma vez que se manteve o regime de sufrágio restrito de base capacitária e não se deram passos para introduzir o sistema proporcional, nem círculos mais coerentes, como em Itália em 1918-19. Manteve-se o sistema eleitoral maioritário de lista incompleta (se o círculo elegia três deputados, o eleitor só podia votar em dois nomes) que assegurava a representação dos principais partidos minoritários, mas dava vantagem ao partido dominante. Continuaram a persistir índices de abstenção elevados e os partidos políticos continuaram a negligenciar a integração social e política das massas. Os partidos políticos estavam muito descredibilizados em Portugal, fruto da manutenção do clientelismo, da fraude nas eleições e das práticas políticas usadas no Parlamento (LOPES, 1994, 2011, 2013a, 2013b; ALMEIDA, 1998, 2012). 
A opinião pública tinha dificuldade em aceitar que muitas sessões do Congresso não se realizassem por falta de quórum, ou que os deputados usassem todos os procedimentos regimentais legais e ilegais para obstaculizar o fim do debate e a votação final das leis ou de moções de censura. O uso do obstrucionismo foi uma prática continuada no Parlamento português, à semelhança do que sucedia em Espanha. Um exemplo desta situação ocorreu nos dias 16 e 17 de julho de 1925 durante um debate na Câmara dos Deputados. Pedro Pita, deputado do Partido Republicano Nacionalista, apresentou uma moção de censura contra o governo do PRP liderado por António Maria da Silva. Os deputados da maioria, vendo que naquele dia estavam em minoria na Câmara dos Deputados, prolongaram os seus discursos até ao limite das suas forças, para que fossem chamados ao Parlamento todos os deputados do PRP em falta, em particular os que estavam no Porto, que só podiam chegar no comboio das 2 horas da tarde do dia seguinte, para assim acudirem ao governo. O primeiro a tomar a palavra foi João Camoesas que, durante o seu longo discurso de quase 9 horas, dissertou sobre os mais variados assuntos. Tendo iniciado a sua intervenção por volta da meia-noite e meia, caiu exausto por volta das 9 horas e meia da manhã. Nas horas seguintes outros deputados da maioria continuaram a discursar, mas não conseguiram salvar o governo, que viria a cair quando a moção pôde finalmente ser votada. Outra prática obstrucionista comum no Parlamento português era o "Jogo da Porta". Os deputados quando tinham interesse em encerrar uma sessão da Câmara dos Deputados, impedindo uma votação, usavam a estratégia de pedir a contagem dos parlamentares, colocando-se alguns deputados fora da sala. Todavia, quando se fazia a chamada para o pagamento do abono regressavam imediatamente à sala. O "Jogo da Porta" também servia para os deputados não votarem algum diploma legal de que discordavam, mas sobre o qual não queriam tomar partido, pelo que o resultado das votações era muitas vezes imprevisível. Noutras ocasiões os protestos, batuques e consequentes tumultos e agressões entre deputados e senadores, impediam que as sessões prosseguissem. Alguns partidos minoritários também usaram como tática abandonar o Congresso em protesto por algumas semanas ou meses, como forma de descredibilizar a maioria e o Parlamento. Durante estes anos o processo legislativo tornou-se cada vez mais complexo e demorado, pelo que o Congresso passou a ser conotado como um órgão ineficaz (FARINHA, 2004; FERNANDES, 2012; BAIÔA, 2015).

Outra prática intrínseca aos partidos políticos portugueses, que a imprensa criticava duramente, era o caciquismo. O clientelismo na Primeira República seguiu o 
modelo existente na Europa do Sul e manteve algumas características do período da Monarquia. Apenas ganhou um cunho mais urbano e administrativo, onde os funcionários públicos desempenhavam um papel fundamental. Os caciques controlavam o recenseamento eleitoral, a distribuição de empregos, a recolocação dos funcionários públicos em lugares melhores, a distribuição de senhas para a aquisição de alimentos, o arrendamento de casas estatais e a adjudicação de obras aos amigos, entre outras benesses. Já os adversários podiam contar com a aplicação de multas, taxas, impostos e o afastamento dos funcionários públicos para longe ou mesmo o seu saneamento. Os caciques do Partido Republicano Português controlavam as melhores posições e recursos dentro do aparelho de Estado. Em maio de 1919, no mesmo mês em que ocorreram as eleições legislativas, o governo liderado pelo PRP nomeou e promoveu milhares de funcionários públicos, muitos deles impreparados para as funções, ao mesmo tempo que lhes aumentava o vencimento. Contudo, os notáveis dos partidos da oposição também controlavam alguns sectores públicos e privados, pelo que também distribuíam muitos favores. Todavia, o PRP era o partido que melhor controlava a gestão da violência política, através de inúmeras milícias armadas republicanas toleradas pelas autoridades (LYTTELTON，1973; VARELA ORTEGA， 1977， 2001; GRAZIANO， 1980; GELLNER, 1986; ALMEIDA, 1991; CAZORLA PÉREZ, 1992; LOPES, 1994, 2013a; MORENO LUZON, 1995, 1999, 2006; ROBLES EGEA, 1996; FORNER, 1997; SILVA, 1997; TELO, 2011; BAIÔA, 2013).

A organização partidária modernizou-se pouco, continuando com a mesma estrutura personalista de carácter oligárquico e caciquil que afastava a maioria dos seus membros das decisões e mantinha a população afastada da política. Os atos eleitorais internos dos partidos e as eleições gerais continuaram pouco transparentes e não foi possível consolidarem-se novos partidos de integração social que renovassem os líderes políticos e os seus procedimentos. Esta imagem de organização clientelar transparecia para a opinião pública por meio de uma imprensa cada vez mais crítica em relação à ineficácia dos partidos e do Parlamento que não conseguia aprovar o orçamento na maior parte dos anos. A modernização e a democratização não foram requeridas intensamente pela sociedade, nem foram sugeridas pelos partidos. A continuação das práticas clientelares dos partidos de notáveis, a pouca lisura nos atos eleitorais e a ineficácia dos órgãos de soberania acentuaram a crise de legitimidade das instituições políticas e impeliram para fora do sistema político vastos grupos da sociedade que desenvolveram 
petições desproporcionadas e atividades subversivas (LOPES, 1994, 2004, 2011, 2013a; ALMEIDA, 1991, 2012; SILVA, 1997; BAIÔA, 2015).

No início da década de vinte, os principais partidos da I República já não eram “puros partidos de notáveis", à semelhança do que sucedia no mesmo período na Grécia e em Espanha, uma vez que tinham iniciado uma modernização e adaptação aos novos tempos. Estes partidos ainda estavam distantes dos partidos de massas, mas eram naquele momento bastante mais evoluídos que os tradicionais partidos de notáveis do século XIX. Estas organizações políticas ainda eram dominadas pela elite parlamentar e pelos exministros e pelas suas clientelas de notáveis regionais e caciques locais, quando na Europa Ocidental se afirmavam os partidos de massas (BERNSTEIN, 1980; MAVROGORDATOS, 1983; ARRANZ NOTARIO, 1995; SIERRA, 1996; ORSINI \& QUAGLIARIELLO, 1996; SILVA, 1996; LUEBBERT, 1997; PEÑA GUERRERO, 1998; VARELA ORTEGA, 2001; MORENO LUZÓN, 2006; BAIÔA, 2015).

Os principais dirigentes dos partidos republicanos pertenciam às elites urbanas, embora com uma origem social mais modesta e com menores ligações de parentesco, quando comparados com os da Monarquia. A nível profissional, distinguiam-se os funcionários públicos, com uma presença esmagadora. Dentro dos funcionários públicos destacavam-se os militares, altos funcionários da administração pública, magistrados e professores. Os juristas, em particular os advogados, e os médicos também tinham um peso importante. Os políticos ligados em exclusivo à atividade agrícola, comercial e industrial eram minoritários na cúpula dos principais partidos da I República. A classe dirigente dos partidos estruturais da I República tinha uma elevada formação académica, uma vez que mais de $80 \%$ tinha estudado em instituições de ensino superior. Destacavamse essencialmente três qualificações: direito, formação militar e medicina. Comparando com os partidos europeus da mesma época, e particularmente com os da Europa do Norte, a elite partidária portuguesa tinha uma formação académica mais elevada. Esta diferença torna-se ainda mais acentuada quando se compara os dirigentes dos partidos portugueses com os dirigentes dos partidos de massas em afirmação na Europa dos anos vinte. Outra diferença notória é o peso maior da qualificação militar na elite partidária portuguesa. A excessiva politização das Forças Armadas acabou por ser desastrosa para o regime, uma vez que Portugal passou a ter um número exagerado de oficiais no pós-guerra descontentes com o seu salário. A ascensão dos políticos portugueses na hierarquia do partido era mais rápida e não era necessária uma experiência na política local para chegar aos lugares de topo, como acontecia em muitos partidos europeus, pelo que era comum 
chegar-se à direção central de um partido antes dos 40 anos. Os dirigentes secundários dos partidos políticos estavam ligados aos notáveis por laços familiares e profissionais, mas principalmente por pura sobrevivência económica. Necessitavam dos notáveis para terem uma vida digna e por isso desempenhavam todo tipo de tarefas dentro do partido, desde a distribuição de panfletos porta a porta, até esmurrar um adversário que tinha ofendido o seu padrinho. Faziam ainda a ligação entre a massa popular e os principais dirigentes do partido, sendo por isso, um elemento fundamental na dinâmica organizacional dos partidos (SILVA, 1996; MARQUES, 2000; BEST \& COTTA, 2000; ALMEIDA \& PINTO \& BERMEO, 2003; ALMEIDA \& FERNANDES \& SANTOS, 2006; QUEIRÓS, 2008; LEAL, 2008; ALMEIDA, 2012; BAIÔA, 2014).

A tomada de decisões importantes nos partidos portugueses estava centralizada no Diretório e no grupo parlamentar, ainda que o Congresso fosse o órgão supremo dos partidos e os notáveis regionais gozassem de ampla liberdade. As estruturas locais dos partidos estavam dominadas pelos caciques que tinham uma grande autonomia funcional, pelo que podiam realizar alianças com base em interesses estratégicos e familiares, desprezando as teorias ideológicas. Os partidos continuavam a ter um funcionamento interno deficiente e irregular. Eram normalmente confederações pouco coesas e flexíveis de comissões locais independentes, chefiadas por um cacique, com uma fraca conexão horizontal e vertical com as outras estruturas partidárias. As relações dentro do partido eram acima de tudo pessoais e não institucionais. O dinamismo do partido assentava mais no somatório da força dos seus notáveis, do que no partido enquanto organização. Os membros de base dos partidos continuavam a estar vinculados a um notável e não diretamente ao partido, enquanto organismo. Manuel Gregório Pestana Júnior, destacado membro do Partido Republicano Português, explicou o que representava pertencer a um partido entre o final do século XIX e o início do século XX. Nessa altura pouco importava: "Ser-se republicano, regenerador ou progressista, tinha apenas de ser-se dedicado ao $\mathrm{Sr}$. $\mathrm{A}, \mathrm{B}$, ou $\mathrm{C}$ e se perguntasse aos políticos de então o que era ser republicano, regenerador ou progressista, a maior parte admirar-se-ia da pergunta e limitar-se-ia a dizer: eu sou do Sr. B, ou do Sr. C.” (Radical, 6-8-1911).

$\mathrm{Na}$ maior parte das localidades a mobilização política existia apenas nos momentos eleitorais. A organização e a burocracia partidária eram muito débeis e resumiam-se muitas vezes apenas a relações pessoais, a comissões políticas com atividade limitada aos períodos eleitorais, a centros associativo-partidários nas cidades e a alguns jornais nacionais e regionais. As reuniões partidárias realizavam-se nos centros 
partidários ou nas residências dos líderes. Durante estas reuniões havia o que se pode chamar "decisão por interpretação". As reuniões eram mais para os patronos transmitirem aos seus clientes as suas ideias e posições, do que para debater. As propostas eram normalmente aprovadas por ovação e não por votação. Existia uma clara falta de transparência, pluralismo e democracia dentro destes partidos. Existia pouca competição nas eleições internas, mas quando várias correntes se enfrentavam nas urnas, o resultado final era quase sempre uma nova dissidência partidária protagonizada pelos perdedores. O sistema de registo dos membros era ainda muito arcaico e organizava-se junto das estruturas locais, sem o controlo e a supervisão das estruturas nacionais. Os partidos portugueses tinham um aparato organizativo bastante simples, ainda sem um rol de funcionários típico dos partidos de massas. O financiamento deste tipo de partidos passava já pelo contributo individual de cada membro, embora cada um pagasse consoante o seu estatuto social e permanecessem muito dependentes de receitas extraordinárias provenientes da fortuna pessoal dos notáveis, pelo que a falta de dinheiro foi uma constante. Além disso, por norma, os partidos, eram fracamente doutrinados mas profundamente pragmáticos. Não ambicionavam mobilizar grandes massas populacionais, nem transmitir uma imagem e uma identidade coletiva forte e consistente. Os seus aderentes tinham uma disciplina e fidelidade ideológica exígua e a relação com os seus eleitores não era baseada em mecanismos de delegação mas de confiança. O seu objetivo central era ter acesso privilegiado aos recursos do Estado e aliciar o maior número de influentes regionais e locais, dado que este tipo de partidos era composto pelo somatório dos notáveis e das suas clientelas locais. Estes notáveis podiam proporcionar prestígio, capacidade técnica e capital ao partido. A coesão interna mantinha-se pela perspetiva de distribuição de favores coletivos (uma estrada ou uma escola para uma localidade) e individuais (recomendações para empregos ou resolução de problemas burocráticos com a administração pública) dos patronos aos seus "afilhados", em troca de apoio político durante o processo eleitoral. A indisciplina, a fragmentação e as cisões neste tipo de partido foram frequentes, devido principalmente a diferenças pessoais e lutas de liderança. Estas cisões provocavam uma associação de notáveis e seus amigos em torno dos novos líderes com ramificações por todo o país, dando lugar, por vezes, à formação de um novo partido (LOPES, 1994, 2013a, 2013b; SILVA, 1996; QUEIRÓS, 2008; LEAL, 2008; BAIÔA, 2015).

O Partido Republicano Português e os outros partidos portugueses não se transformaram em partidos de massas. Continuou a haver nestes partidos um desajuste e 
afastamento progressivo entre as reivindicações urbanas mais democratizadas e participativas, e, por outro lado, a manutenção da estrutura elitista de um partido de notáveis, com uma conceção monopolista, hierárquica e fechada do poder. No entanto, alguns partidos portugueses começaram a sua modernização, aproximando-se do modelo de partido de quadros nos principais meios urbanos, com destaque para o Partido Republicano Português, que foi o único partido que manteve uma base organizacional e eleitoral forte e uniforme em todo o território português. Contudo, continuaram a persistir em Portugal partidos com uma organização política mais arcaica, de base quase exclusivamente parlamentar, com uma débil ou inexistente rede organizativa a nível nacional, como o Grupo Parlamentar de Ação Republicana entre 1924 e 1925 (SILVA, 1996; BAIÔA, 2015).

A sociedade portuguesa encontrava-se num processo de transição, combinando traços modernos, com elementos arcaicos. Os partidos políticos portugueses foram influenciados por este contexto, pelo que nas cidades, particularmente em Lisboa, contavam com uma estrutura que os aproximava dos partidos de quadros. No entanto, nos meios rurais continuavam com uma organização e uma prática política típica dos partidos de notáveis. O atraso da economia e da sociedade portuguesa e o facto de o regime republicano ter um cariz revolucionário, incapaz de gerar paz social e compromissos, atrasou a metamorfose interna dos partidos portugueses no sentido que se estava a operar em alguns países europeus - cooperação com o lento processo de democratização - ainda que isso significasse, a médio prazo, a superação destes partidos de notáveis por parte dos partidos de massas. Em relação a outros países da Europa do Sul, verificou-se um atraso considerável na modernização dos partidos políticos portugueses. Os partidos de quadros espanhóis ainda que continuassem acomodados às práticas clientelares, deram sinais de seguir as correntes democráticas da Europa do pós-guerra, com um programa reformista gradual que contrabalançava as ameaças revolucionárias. Os partidos de quadros italianos tiveram muita dificuldade em adaptar-se ao alargamento do sufrágio e à representação proporcional introduzida em 1919, o que permitiu um reforço da influência política dos modernos partidos de integração social, como o Socialista e o Popular (SUÁREZ CORTINA, 1986; RIDOLFI, 1992, 1999; POMBENI, 1994; NOIRET, 1994, 1997a, 1997b; ORSINI \& QUAGLIARIELLO, 1996; SILVA, 1996; TARCHI, 2000; VARELA ORTEGA, 2001; LOTTI, 2002; MORENO LUZÓN, 2004; ROSAS, 2010; BAIÔA, 2015). 
A transição para a democracia em Portugal não dependeu só da vontade das elites políticas nacionais e locais, mas principalmente da sociedade no seu todo. A sociedade portuguesa dos anos vinte não estava ainda preparada para conseguir dar estabilidade a um sistema de democracia representativa, nem a outro tipo de partidos, como os partidos de integração social de massas, nomeadamente os socialistas, comunistas e fascistas. Os partidos portugueses inseridos numa sociedade civil frágil continuaram a basear-se nas elites, desprezando as massas. O sistema político e social português tinha algumas características que o aproximavam mais dos regimes políticos da Europa Oriental e da América do Sul do que da Europa Ocidental, com uma sociedade rural, uma industrialização tardia e uma economia arcaica, inserida num sistema político de tradição parlamentar, mas de competição e pluralismo limitado e com um baixo nível de mobilização política que facilitou a transição para uma ditadura de características tradicionais, onde a mobilização fascista era desnecessária ou mesmo prejudicial para proteger os interesses das elites dominantes (MOUZELIS, 1986; DOGAN, 1987; LOPES, 1994, 2004; SILVA, 1997; RAMOS, 2001, 2004; PINTO, 2004; BAIÔA, 2015).

Em suma, durante a fase final da Primeira República (1919-1926) não se deram passos consistentes para a democratização do sistema político e os partidos nem conseguiram chegar a acordos mínimos que defendessem o sistema republicano-liberal. Portugal continuou amarrado à tradição liberal e oligárquica do século XIX, ainda que numa versão republicana e com um sistema multipartidário de partido dominante com uma crescente falta de legitimidade. A desconfiança nos políticos, no sistema eleitoral e nos partidos políticos levou a que vastos interesses económicos e sociais buscassem uma representação e uma atuação direta perante o poder, sem nenhum tipo de mediação política, dado que não se sentiam suficientemente representados e defendidos pelo Parlamento, pelos partidos e pelo governo. O descrédito dos partidos enquanto organizações de mediação da sociedade com o poder político e a necessidade de criar um governo forte, fora dos partidos, também encontrou acolhimento entre as Forças Armadas, as organizações patronais, os sindicatos, as forças antiliberais e o movimento católico. Estas organizações viraram-se sobre si mesmas numa "estratégia corporativa" de reforço orgânico, contra as instituições republicanas e contra os partidos tradicionais.

\section{Fontes}

A Tarde, Lisboa, 1923.

Radical, Lisboa, 1911. 


\section{Referências Bibliográficas}

AFONSO, Aniceto (2001). História de uma conspiração: Sinel de Cordes e o 28 de Maio. Lisboa: Editorial Notícias.

ALMEIDA, Pedro Tavares de \& FERNANDES, Paulo Jorge \& SANTOS, Marta Carvalho dos (2006). Os Deputados da 1. a República Portuguesa: Inquérito Prosopográfico. Revista de História das Ideias, Coimbra, Vol. 27, pp. 399-417.

ALMEIDA, Pedro Tavares de \& MORENO LUZÓN, Javier (Coord.) (2012). Das Urnas ao Hemiciclo. Eleições e Parlamento em Portugal (1878-1926) e Espanha (18751923). Lisboa: Assembleia da República.

ALMEIDA, Pedro Tavares de \& PINTO, António Costa \& BERMEO, Nancy (Ed.). (2003). Who Governs Southern Europe? Regime Change and Ministerial Recruitment (1850-2000). London: Frank Cass.

ALMEIDA, Pedro Tavares de (1991). Eleições e Caciquismo no Portugal Oitocentista (1868-1890). Lisboa: Difer.

ALMEIDA, Pedro Tavares de (Organização e introdução de). (1998). Legislação eleitoral portuguesa: 1820-1926. Lisboa: Imprensa Nacional - Casa da Moeda.

ALMEIDA, Pedro Tavares de (2012). Eleições e recrutamento parlamentar em Portugal. In: ALMEIDA, Pedro Tavares de \& MORENO LUZÓN, Javier (Coord.). Das Urnas ao Hemiciclo. Eleições e Parlamento em Portugal (1878-1926) e Espanha (1875-1923). Lisboa: Assembleia da República, pp. 17-46.

ÁLVAREZ REY, Leandro (1987). Sevilla durante la Dictadura de Primo de Rivera. La Unión Patriótica Sevillana - 1923-1930. Sevilla: Diputación Provincial de Sevilla.

ARRANZ NOTARIO, Luis (1995). Modelos de partido. Ayer. Madrid, n. ${ }^{\circ}$ 20, pp. 81110.

BAIÔA, Manuel (2000). Elites políticas em Évora da I República à Ditadura Militar (1925-1926). Lisboa: Edições Cosmos.

BAIÔA, Manuel (Ed.) (2004). Elites e Poder. A Crise do Sistema Liberal em Portugal e Espanha (1918-1931). Lisboa: Edições Colibri/CIDEHUS.UE.

BAIÔA, Manuel (2013). O Partido Republicano Nacionalista e o Clientelismo (19231935). In: ROLLO, Maria Fernanda \& RIBEIRO, Maria Manuela Tavares \& PIRES, Ana Paula; NUNES, João Paulo Avelãs (Coords.). Atas I Congresso de História Contemporânea. IHC / CEIS20 / Rede História, pp. 326-338

BAIÔA, Manuel (2014). A elite do Partido Republicano Nacionalista (1923-1935): perfil social e sociabilidade. História, Revista da FLUP, Faculdade de Letras da Universidade do Porto, IV Série, vol. 4, pp. 187-200.

BAIÔA, Manuel (2015). O Partido Republicano Nacionalista 1923-1935. «Uma República para Todos os Portugueses». Lisboa: ICS-Imprensa de Ciências Sociais.

BERG-SCHLOSSER, Dirk \& MITCHELL, Jeremy (Edited by) (2000). Conditions of Democracy in Europe, 1919-39. Systematic Case Studis. London: Macmillan Press.

BERNSTEIN, Serge (1980). Histoire du Parti Radical. La Recherche de L'Age D'Or (1919-1926). Paris: Presses de la Fondation National des Sciences Politiques.

BEST, Heinrich \& COTTA, Maurizio (Edited by) (2000). Parliamentary Representatives in Europe 1848-2000. Legislative Recruitment and Careers in Eleven European Countries. Oxford: Oxford University Press.

CAPOCCIA, Giovanni (2001). Defending democracy: Reactions to political extremism in inter-war Europe. European Journal of Political Research. n. 39, pp. 431-460. 
CARRILHO, Maria (1985). Forças Armadas e Mudança Política em Portugal no século XX. Para uma explicação sociológica do papel dos militares. Lisboa: Imprensa Nacional - Casa da Moeda.

CAZORLA PÉREZ, José (1992). Del Clientelismo tradicional al clientelismo de partido: evolución y características. Working Papers. Institut de Ciènces Politiques i Socials, n. ${ }^{\circ} 55$.

COSTA, Fernando Marques da (2001). Bernardino Machado. In: PINTO, António Costa (Coord.). Os Presidentes da República Portuguesa. Amadora: Círculo de Leitores, pp. 60-71.

DARDÉ, Carlos (2012). Eleições e recrutamento parlamentar em Espanha. In: ALMEIDA, Pedro Tavares de \& MORENO LUZÓN, Javier (Coord.). Das Urnas ao Hemiciclo. Eleições e Parlamento em Portugal (1878-1926) e Espanha (18751923). Lisboa: Assembleia da República, pp. 47-70.

DOGAN, Mattei (1987). Romania, 1919-1938. In: WEINER, Myron; OZBUDUN, Ergun (Edited by). Competitive elections in developing countries. Durham: Duke U.P., pp. 369-389.

ERTMAN, Thomas (1998). Democracy and Dictatorship in Interwar Western Europe Revisited. World Politics, 50 (3), pp. 475-505.

FARINHA, Luís (1998). O Reviralho: Revoltas republicanas contra a Ditadura e o Estado Novo 1926-1940. Lisboa: Editorial Estampa.

FARINHA, Luís (2004). O Parlamento Republicano. Funcionamento e Reformas (19181926). In: BAIÔA, Manuel (Ed.). Elites e Poder. A Crise do Sistema Liberal em Portugal e Espanha (1918-1931). Lisboa: Edições Colibri/CIDEHUS.UE, pp. 4977.

FERNANDES, Paulo Jorge (2012). O papel político e o funcionamento do parlamento em Portugal. In: ALMEIDA, Pedro Tavares de \& MORENO LUZÓN, Javier (Coord.). Das Urnas ao Hemiciclo. Eleições e Parlamento em Portugal (18781926) e Espanha (1875-1923). Lisboa: Assembleia da República, pp. 103-131.

FERREIRA, José Medeiros (1992). O comportamento político dos militares. Forças armadas e regimes políticos em Portugal. Lisboa: Ed. Estampa.

FORNER, Salvador (Coord.) (1997). Democracia, elecciones y modernización en Europa. Siglos XIX y XX. Madrid: Cátedra.

FREIRE, André (2011). Eleições, sistemas eleitorais e democratização: o caso português em perspectiva histórica e comparativa. In: FREIRE, André (Coord.). Eleições e Sistemas Eleitorais no Século XX Português. Lisboa: Edições Colibri, pp. 25-81.

GELLNER, Ernest et al. (1986). Patronos y Clientes. Barcelona: Jucar Univ.

GÓMEZ-NAVARRO, José Luís (1991). El Régimen de Primo de Rivera. Reyes, Dictaduras y Dictadores. Madrid: Cátedra.

GRAZIANO, Luigi (1980). Clientelismo e sistema politico. Il caso dell'Italia. Milano: Franco Angeli Editore.

JULIÁ, Santos (1996). El sistema de partidos en la Segunda República. Revista de Historia Contemporánea. Universidad de Sevilla, n. ${ }^{\circ}$ 7, pp. 201-219.

LEAL, Ernesto Castro (2008). Partidos e Programas. O campo partidário republicano português (1910-1926). Coimbra: Imprensa da Universidade de Coimbra.

LEAL, Ernesto Castro (2009a). A transformação política da República: as direitas da direita antiliberal. In: ROSAS, Fernando \& ROLLO, Maria Fernanda. História da Primeira República Portuguesa. Lisboa: Tinta-da-china, pp. 485-502.

LEAL, Ernesto Castro (2009b). Parties and Political Identity: the Construction of the Party System of the Portuguese Republic (1910-1926). e-Journal of Portuguese History. vol. 7, n. 1, pp. 37-44. 
LINZ, Juan J. \& STEPAN, Alfred, (Ed.) (1978). The Breakdown of Democratic Regimes. Baltimore: Johns Hopkins U.P.

LINZ, Juan J. (1991), La crisis de las democracias. In: CABRERA Mercedes \& JULIÁ, Santos \& MARTÍN ACEÑA, Pablo (Comps.). Europa en crisis, 1919-1939. Madrid: Editorial Pablo Iglesias, pp. 231-280.

LOPES, Fernando Farelo (1990). Um regime parlamentarista de partido dominante. In: REIS, António (Dir.). Portugal Contemporâneo. Vol. III, Lisboa: Publicações Alfa, pp. 85-100.

LOPES, Fernando Farelo (1994). Poder Político e Caciquismo na 1. ${ }^{a}$ República Portuguesa. Lisboa: Editorial Estampa.

LOPES, Fernando Farelo (2004). Os Partidos Políticos. Modelos e Realidades na Europa Ocidental e em Portugal. Oeiras: Celta Editora.

LOPES, Fernando Farelo (2011). Direito de voto, regime de escrutínio e "eleições feitas" na I República Portuguesa. In: FREIRE, André (Coord.). Eleições e Sistemas Eleitorais no Século XX Português. Lisboa: Edições Colibri, pp. 101-123.

LOPES, Fernando Farelo (2013a). Caciquismo. In: ROLLO, Maria Fernanda (Coordenadora Geral). Dicionário de História da I República e do Republicanismo. Volume I, Lisboa: Assembleia da República, pp. 483-487.

LOPES, Fernando Farelo (2013b). Eleições. In: ROLLO, Maria Fernanda (Coordenadora Geral). Dicionário de História da I República e do Republicanismo. Volume I, Lisboa: Assembleia da República, pp. 1092-1099.

LOTTI, Luigi (2002). I Partiti dal sistema uninominal alla proporzionale: la classe dirigente liberale di fronte all' affermazione dei movimenti di massa. In: GARCIA SANZ, Fernando (Ed.). España e Italia en la Europa Contemporánea: desde finales del siglo XIX a las Dictaduras. Madrid: Consejo Superior de Investigaciones Científicas, pp. 69-76.

LUEBBERT, Gregory M. (1997). Liberalismo, Fascismo o Socialdemocracia. Clases Sociales y orígenes políticos de los regímenes de la Europa de entreguerras. Zaragoza: Prensas Universitarias de Zaragoza.

LYTTELTON, Adrian (1973). El patronazgo de la Italia de Giolitti. Revista de Occidente. Tomo 43, n. ${ }^{\circ} 127$, pp. 94-117, out./dez.

MARQUES, A. H. de Oliveira (1980). A $1 .^{a}$ República Portuguesa (alguns aspectos estruturais). 3. a edição, Lisboa: Livros Horizonte.

MARQUES, A. H. de Oliveira (Coord. de) (1991). Portugal da Monarquia para a República. «Nova História de Portugal», Vol. 11, Lisboa: Editorial Presença.

MARQUES, H. de Oliveira (Coord. de) (2000). Parlamentares e Ministros da $1 .^{a}$ República. Porto: Edições Afrontamento/Assembleia da República.

MARTORELL LINARES, Miguel (2012). "A ação governativa afoga-se num dilúvio de palavras": leis, fiscalização e consenso no parlamento espanhol. In: ALMEIDA, Pedro Tavares de \& MORENO LUZÓN, Javier (Coord.). Das Urnas ao Hemiciclo. Eleições e Parlamento em Portugal (1878-1926) e Espanha (1875-1923). Lisboa: Assembleia da República, pp. 134-164.

MATOS, Luís Salgado de (2010). Tudo o que sempre quis saber sobre a Primeira República em 37 mil palavras. Lisboa: Imprensa de Ciências Sociais.

MAVROGORDATOS, George Th. (1983). Stillborn Republic. Social Coalitions and Party Strategies in Greece, 1922-1936. Berkeley: University of California Press.

MENESES, Filipe Ribeiro de (2004). O impacto da Primeira Guerra Mundial no sistema político português. In: BAIÔA, Manuel (Ed.). Elites e Poder. A Crise do Sistema Liberal em Portugal e Espanha (1918-1931). Lisboa: Edições Colibri/CIDEHUS.UE, pp. 421-446. 
MORENO LUZÓN, Javier (1995). Teoría del clientelismo y estudio de la política caciquil. Revista de Estudios Políticos, n. ${ }^{\circ}$ 89, pp. 191-224, Julio/Septiembre.

MORENO LUZÓN, Javier (1998a). Partidos y Parlamento en la crisis de la Restauración. In: CABRERA, Mercedes (Dir.). Con Luz e Taquígrafos. El Parlamento en la Restauración (1913-1923). Madrid: Taurus, pp. 65-102.

MORENO LUZÓN, Javier (1998b) Romanones. Caciquismo y política liberal. Madrid: Alianza Editorial.

MORENO LUZÓN, Javier (1999). El clientelismo político: Historia de un concepto multidisciplinar. Revista de Estudios Políticos. n. ${ }^{\circ}$ 105, pp. 73-95, Julio/Septiembre.

MORENO LUZÓN, Javier (2004). El Partido Liberal español y la crisis de la Restauración (1917-1923). In: BAIÔA, Manuel (Ed.). Elites e Poder. A Crise do Sistema Liberal em Portugal e Espanha (1918-1931). Lisboa: Edições Colibri/CIDEHUS.UE, pp. 133-164.

MORENO LUZÓN, Javier, (2006). A historiografia sobre o caciquismo espanhol: balanço e novas perspectivas. Análise Social, n. 178, pp. 9-29.

MOUZELIS, Nicos P. (1986). Politics in the Semi-Periphery. Early Parliamentarism and Late Industrialization in the Balkans and Latin America. London: Macmillan.

NOIRET, Serge (1994). La nascita del sistema dei partiti nell'Italia contemporanea. La proporzionale del 1919. Roma: Piero Lacaita editore.

NOIRET, Serge (1997a). La introducción del sufragio universal y de la representación proporcional en Italia en 1918-1919: una frágil modernización democrática. In: FORNER, Salvador (Coord.). Democracia, elecciones y modernización en Europa, Siglos XIX y XX. Madrid: Cátedra, pp. 73-95.

NOIRET, Serge (1997b). Le campagne Elettorali dell'Italia Liberale: dai Comitati al Partitti. In: BALLINI, Pier Luigi (a cura di). Idee di Rapresentanza e Sistemi Elettorali in Italia tra Otto e Novecento. Venezia: Instituto Veneto di Scienze Lettere ed Arti, pp. 383-454.

OLABARRI GORTAZAR, Ignacio (1996). Problemas no resueltos en torno al pronunciamiento de Primo de Rivera. Revista de Historia Contemporánea, Universidad de Sevilla, n. ${ }^{\circ}$ 7, pp. 223-248.

ORSINI, Fabio Grassi \& QUAGLIARIELLO, Gaetano (a cura di) (1996). Il partito político dalla Grande Guerra al Fascismo. Crisi della rapresentanza e riforma dello Stato nell'età dei sistemi politici di massa (1918-1925). Bologna: Il Mulino.

PEÑA GUERRERO, María Antonia (1998). Clientelismo político y poderes periféricos durante la Restauración. Huelva 1874-1923. Huelva: Universidad de Huelva.

PINTO, António Costa (2004). A queda da 1. ${ }^{a}$ República Portuguesa: uma interpretação. In: BAIÔA, Manuel (Ed.), Elites e Poder. A Crise do Sistema Liberal em Portugal e Espanha (1918-1931). Lisboa: Edições Colibri/CIDEHUS.UE, pp. 165-183.

PINTO, Ricardo Leite (1995). União Liberal Republicana (ULR), 1926-1930. Um partido político na transição da I República para o Salazarismo. Polis, n. ${ }^{\circ}$ 4/5, pp. 131-260, jul./dez.

POMBENI, Paolo (1994). Partiti e Sistemi Politici nella Storia Contemporanea (18301968). Bologna: Il Mulino.

QUAGLIARIELLO, Gaetano (1996). Masse, Organizzazione, Manipolazione. Partiti e Sistemi Politici Dopo Il Trauma Della Grande Guerra. In: ORSINI, Fabio Grassi \& QUAGLIARIELLO, Gaetano (a cura di). Il partito político dalla Grande Guerra al Fascismo. Crisi della rapresentanza e riforma dello Stato nell'età dei sistemi politici di massa (1918-1925). Bologna: Il Mulino, pp. 15-71. 
QUEIRÓS, António José Sousa Monteiro de (2008). A Esquerda Democrática e o final da Primeira República. Lisboa: Livros Horizonte.

RAMOS, Rui (2000). O fim da República. Análise Social, n. 153, pp. 1059-1082.

RAMOS, Rui (2001). A Segunda Fundação (1890-1926). «História de Portugal», Vol. VI, Lisboa: Editorial Estampa.

RAMOS, Rui (2004). Foi a Primeira República um regime liberal? Para uma caracterização política do regime republicano português entre 1910-1926. In: BAIÔA, Manuel (Ed.). Elites e Poder. A Crise do Sistema Liberal em Portugal e Espanha (1918-1931). Lisboa: Edições Colibri/CIDEHUS.UE, pp. 185-246.

REY REGUILLO, Fernando del (1992). Propietarios y patronos. La política de las organizaciones económicas en la España de la Restauración (1914-1923). Madrid: Ministerio de Trabajo y Seguridad Social.

RIDOLFI, Maurizio (1992). Il PSI e la nascita del partito di massa, 1892-1922. Roma: Laterza.

RIDOLFI, Maurízio (1999). Interessi e Passioni. Storia dei partiti politici italiani tra l'Europa e il Mediterraneo. Milano: Bruno Mondadori.

RIQUER I PERMANYER, Borja de (1999). Consideraciones sobre historiografía política de la Restauración. In: AAVV. Tuñon de Lara y la Historiografía española. Madrid: Siglo XXI, pp. 123-141.

ROBLES EGEA, Antonio (Comp.) (1996). Política en penumbra. Patronazgo y clientelismo políticos en la España contemporánea. Madrid: Siglo Veintiuno Editores.

ROSAS, Fernando (1994). O Estado Novo (1926-1974). «História de Portugal», Direcção de José Mattoso. vol. VII, Lisboa: Círculo de Leitores.

ROSAS, Fernando (2010). Porque venceu e porque se perdeu a I República. Lisboa: Bertrand Editora.

SABBATUCCI, Giovanni (1996). La crisi del sistema politico liberale. In: ORSINI, Fabio Grassi \& QUAGLIARIELLO, Gaetano (a cura di). Il partito político dalla Grande Guerra al Fascismo. Crisi della rapresentanza e riforma dello Stato nell'età dei sistemi politici di massa (1918-1925). Bologna: Il Mulino, pp. 251-261.

SCHWARTZMAN, Kathleen C. (1989). The Social Origins of Democratic Collapse: The First Portuguese Republic in the Global Economy. Lawrence: Kansas.

SECO SERRANO, Carlos (1986). El cerco de la Monarquía. La ruptura de los partidos dinásticos con Alfonso XIII durante la Dictadura de Primo de Rivera. Boletín de la Real Academia de la Historia. Tomo CLXXIII, Cuaderno II, pp. 161-269.

SERNERI, Simone Neri (1996). Partiti, Parlamento e Governo: Dal Liberalismo al Fascismo. In: ORSINI, Fabio Grassi \& QUAGLIARIELLO, Gaetano (a cura di). Il partito político dalla Grande Guerra al Fascismo. Crisi della rapresentanza e riforma dello Stato nell'età dei sistemi politici di massa (1918-1925). Bologna: Il Mulino, pp. 263-301.

SIERRA, María (1996). La política del pacto. El sistema de la restauración a través del partido conservador sevillano (1874-1923). Sevilla: Diputación de Sevilla.

SILVA, João Manuel Garcia Salazar Gonçalves da (1996). O Partido Reconstituinte: Clientelismo, faccionalismo e a descredibilização dos partidos políticos durante a Primeira República (1920-1923). Tese (Mestrado). Instituto de Ciências Sociais da Universidade de Lisboa. Lisboa.

SILVA, João Manuel Gonçalves da (1997). O clientelismo partidário durante a I República: o caso do Partido Reconstituinte (1920-1923). Análise Social, n. ${ }^{\circ}$ 140, pp. 31-74. 
SOUSA, Marcelo Rebelo de (1983). Os Partidos Políticos no Direito Constitucional Português. Braga: Livraria Cruz.

SUÁREZ CORTINA, Manuel (1986). El Reformismo en España. Republicanos y Reformistas bajo la Monarquía de Alfonso XIII. Madrid: Siglo Veintiuno.

SUÁREZ CORTINA, Manuel (Ed.) (1997). La Restauración entre el liberalismo y la democracia. Madrid: Alianza.

TARCHI, Marco (2000). Italy: Early Crisis and Fascist Takeover. In: BERGSCHLOSSER, Dirk \& MITCHELL, Jeremy (Edited by). Conditions of Democracy in Europe, 1919-39. Systematic Case Studis. London: Macmillan Press, pp. 294320.

TELO, António José (2011). Primeira República II. Como Cai Um Regime. Lisboa: Editorial Presença.

VARElA ORTEGA, José (1977). Los Amigos Políticos. Partidos, Elecciones y Caciquismo en la Restauración (1875-1900). Madrid: Alianza Universidad.

VARELA ORTEGA, José (1997a). Orígenes e desarrollo de la democracia. Ayer, n. ${ }^{\circ}$ 28, pp. 29-60.

VARELA ORTEGA, José (1997b). De los orígenes de la democracia en España, 18451923. In: FORNER, Salvador (Coord.). Democracia, elecciones y modernización en Europa, Siglos XIX y XX. Madrid: Cátedra, pp. 129-201.

VARELA ORTEGA, José (Director) (2001). El poder de la influencia. Geografía del caciquismo en España (1875-1923). Madrid: Marcial Pons.

Artigo recebido em 20 de março de 2017.

Aprovado em 11 de maio de 2017.

DOI: 10.12957/intellectus.2017.29873 